\title{
Что говорит статистика о пространстве СЭВ
}

Г.Д. КОВАЛЕВА, кандидат экономических наук. E-mail: GDKOV@ieie.nsc.ru А.В. ШЕВЕЛЕВ, Институт экономики и организации промышленного производства СО РАН, Новосибирск. E-mail: andrew.shevelev@gmail.com

В статье рассматриваются результаты исследований структурных особенностей и изменений в экономике на пространстве действующего СЭВ и после его развала на базе рядов ВВП в постоянных ценах. Анализируются последствия дезинтеграции СЭВ и СССР. Для каждого этапа выявлены типы развития стран, построены динамические модели и рассчитаны прогнозы, с высокой точностью предсказавшие кризисные процессы современной экономики и оценки на будущее.

Ключевые слова: Совет экономической взаимопомощи, СССР, валовой внутренний продукт, факторный анализ, трендциклическая модель, прогноз, кризис

«Если хочешь рассмешить бога, то расскажи ему о будущем», но «смеется тот, кто смеется последним!»

Исследования внешнеэкономических связей сибирских регионов, разработка стратегии и программ их развития неразрывно связаны с состоянием международных отношений России, трансформируемых через призму региональных интересов. При этом усиливается и потребность в географической диверсификации региональной торговли. Сейчас, в период преобладания интересов на Востоке и организации Евразийского экономического союза на постсоветском пространстве [1], самое время критически посмотреть на состояние региональных связей на западном направлении, особенно на потенциал стран Восточной Европы, некогда игравших огромную, если не определяющую роль в торговле регионов Сибири ${ }^{1}$. Фундамент сотрудничества регионов с этими странами был заложен еще их членством в Совете экономической взаимопомощи ${ }^{2}$.

\footnotetext{
1 Так, на долю Венгрии и Румынии приходилось 26,8\% экспорта Сибири в 1992 г. [2].

${ }^{2}$ Совет экономической взаимопомощи (СЭВ) - межправительственная экономическая организация, действовавшая с 1949 по 1991 гг., созданная по решению экономического совещания представителей Болгарии, Венгрии, Польши, Румынии, СССР и Чехословакии. В последующие годы в Совет также входили: ГДР (1950-1990 гг.), Монголия (с 1962 г.), Албания (1949-1961 гг.), Куба (с 1972 г.) и Вьетнам (с 1978 г.).
} 


\section{Экскурс в историю:}

\section{экономика, демография и внешняя торговля}

Потенциал сотрудничества Сибири с Восточной Европой сегодня мало востребован, хотя богатая история их отношений дает основание думать, что это временно. Рассмотрим этапы развития экономической интеграции и причины ее ликвидации, а также соотношения масштабов экономик стран на пространстве некогда могущественного объединения.

Целью СЭВ было содействие развитию стран, ускорение индустриализации, рост производительности труда, и, в конечном итоге, - повышение уровня жизни. Приоритеты отдавались научно-техническому и экономическому сотрудничеству, включая развитие взаимной торговли, обмен хозяйственным опытом, помощь в обеспечении сырьем, продовольствием, оборудованием, машинами.

Тесная интеграция до 1991 г. реализовывалась не только в форме масштабной торговли, но и кооперационных связей, отраслевой специализации, создания производств, связанных едиными технологическими цепочками. Многие предприятия Сибири в тот период сотрудничали с предприятиями стран Восточной Европы, а в условиях производственных связей активно развивалась и взаимная торговля. Так, в 1989 г. на страны СЭВ приходилось 55,6\% товарооборота СССР, в том числе 69,6 млрд долл. в экспорте и 73,76 млрд долл. - в импорте (экспорт СССР достигал 113,5 млрд долл., импорт - 118,97 млрд долл. при курсе 1 руб. за 0,606 долл.). Социалистические страны были основным рынком сбыта для советских металлорежущих станков, кузнечнопрессовых машин, дизелей и дизельных генераторов, половины доменного и сталеплавильного оборудования, оборудования для пищевкусовой, текстильной и других отраслей. Одновременно из этих стран импортировалось в СССР до $40 \%$ оборудования, в том числе доменного, сталеплавильного, прокатного, а также промышленных роботов, свыше 30,5\% железнодорожных кранов и 100\% троллейбусов и трамвайных вагонов. В 1963 г. был организован Международный банк экономического сотрудничества (МБЭС), обслуживающий торговлю между странами СЭВ в переводных рублях ${ }^{3}$.

${ }^{3}$ МБЭС продолжает действовать и в настоящее время, его членами остаются Болгария, Вьетнам, Монголия, Польша, РФ, Румыния, Словакия, Чехия.
Интеграция глубоко пронизывала отношения стран. В рамках СЭВ регулировались вопросы развития транспортной инфраструктуры, связи, включая космическую, внедрялось в практику консультирование, действовали единые стандарты и производственные нормы, проводились совместные исследования в области теории и практики управления общественным производством, согласовывались народнохозяйственные планы по выравниванию уровня экономического развития.

Предложения органов СЭВ были рекомендательными, но на деле их выполнение жестко контролировалось партийными структурами. С 1949 г. по 1972 г. интеграция способствовала успешному развитию стран СЭВ, и в середине 1970-х годов на их долю приходилась почти треть мирового промышленного производства.

Однако с 1973 г. проявляются разногласия, непонимание и как следствие - спад в сотрудничестве. Толчком послужил мировой экономический кризис 1973-1974 гг., скачок цен на нефть и развитие нефтедобычи ${ }^{4}$ в отдельных странах. В СССР началась глубокая структурная перестройка в пользу сырьевого сектора, последствия которой не удается преодолеть до настоящего времени. Ускоренный рост в одних странах на фоне замедленного развития в других усиливал экономическую дифференциацию, хотя провозглашалась цель «равного развития». При этом сильные страны (Чехословакия, СССР) проигрывали, а слабые (например, Румыния, Болгария, Венгрия) - выигрывали от углубления интеграции. Развитие СЭВ как системы замедлилось, а смена режимов в отдельных странах в конце 1980-х годов привела к усилению их взаимодействия с западноевропейскими экономиками. Успешные страны СЭВ стали игнорировать внутренний рынок и все чаще выходить на рынки Западной Европы, США и Японии.

Расчеты по клирингу порождали недоверие между участниками, а желание правительств получать оплату в твердой валюте привело к резкому сокращению взаимной торговли. В 1990 г. без всякого переходного периода было объявлено об окончании расчетов между странами СЭВ в переводных рублях и переходе к расчетам в долларах США по мировым ценам. Для большинства

${ }^{4}$ Доля СССР в мировой добыче нефти в натуральном измерении с $15 \%$ в 1970 г. возросла до19,5\% в 1980 г. и до 21,8\% в 1985 г. (из них 13,1\% приходилось на РФ). 
стран это было катастрофой: они не имели нужного объема твердой валюты для поддержания торговых отношений, клиринговые (бартерные) цены значительно отличались от мировых. Дезинтеграции способствовали также бюрократизация, неработающие программы и т. д. Распад СЭВ был предрешен, и 28 июня 1991 г. в Будапеште Болгария, Венгрия, Вьетнам, Куба, Монголия, Польша, Румыния, СССР и Чехословакия на 46-м заседании сессии Совета подписали Протокол о расформировании организации.

Считается, что прекращение экономического сотрудничества в СЭВ ударило по всем участникам. Попытаемся проанализировать тренды движения экономики этих стран и причины, обусловившие экономическую динамику, а также выявить странылидеры, с которыми сотрудничество регионов Сибирского федерального округа наиболее перспективно. Для этого рассмотрены результаты девяти стран-членов СЭВ с 1970 по 1990 гг. и 24 стран, расположенных на той же территории после прекращения деятельности СЭВ и СССР (в том числе новых постсоветских государств - бывших республик СССР), за 1991-2012 гг. ГДР была исключена из анализа с целью обеспечения сопоставимости оценок до и после развала СЭВ.

Если рассматривать численность населения как индикатор, в некоторой степени отражающий эффекты интеграции и дезинтеграции, то ситуация такова (расчеты по данным $\mathrm{OOH}$ от 20.04.2015 г. [3]). За 43 года суммарная численность населения 24 стран возросла с 380 млн чел. в 1970 г. до 487 млн чел. в 2013 г., т. е. почти на четверть, прирастая в среднем за год на 2,49 млн чел.

Самой крупной страной с большим отрывом по численности населения была и остается Россия (143,5 млн чел. в 2013 г.). Второе место занял Вьетнам, население которого за эти годы более чем удвоилось и превысило 89,7 млн чел., потеснив на третье место Украину (45,5 млн чел. в 2013 г.). На четвертом месте - Польша с населением 38,5 млн чел. - самая крупная страна Восточной Европы, а на пятом - Узбекистан с населением 30,2 млн чел. - лидер в Средней Азии. Замыкали рейтинг страны Балтии: Литва (3 млн чел.), Латвия (2 млн чел.) и Эстония (1,3 млн чел.).

При этом население на пространстве СЭВ росло в основном в 1970-1991 гг. Суммарный прирост за эти годы составил
87,5 млн чел. и был обеспечен увеличением на $30 \%$ населения Вьетнама, на 21\% - России, на $11 \%$ - Узбекистана, на 7\% - Польши и $6 \%$ - Украины. Прирост населения в остальных странах до 1991 г. был менее значительным - от 4,2\% (Казахстан) до 0,04\% (Венгрия). На всем пространстве не было ни одной страны, где бы население в 1970-1991 гг. сократилось.

С 1992 г. все резко изменилось. Из-за экономической и политической нестабильности, а также ухудшения социально-экономических условий в большинстве стран численность сокращалась за счет снижения не только рождаемости, но и эмиграции населения. Среди 24 стран по потерям за последние два десятилетия лидировала Украина, недосчитавшаяся к 2013 г. 6,7 млн чел., т. е. $13 \%$ от общей численности ее населения в 1992 г., на втором месте - Россия, население которой сократилось на 5,2 млн чел. (3\% от численности 1992 г.), третьем - Румыния, потерявшая 2,8 млн чел. (снижение на 12\%). В Болгарии население уменьшилось на $15 \%$, Венгрии - 5\%, в Белоруссии - на 7\%. Но самая критическая ситуация сложилась в странах Балтии. В Латвии к 2013 г. население сократилось на 23\%, в Литве - 20\%, а в Эстонии - на $14 \%$

Мыслли вслух. Остановился ли этот процесс? Все ли, кто хотел - уехали в поисках лучшего «на Запад»? Не исключено, что Евросоюз, расширяя и ужесточая сферы регулирования для своих членов, повторяет ошибки СЭВ, и, как любую жесткую систему, его ждет та же судьба? Толчком может оказаться не только возрастающая экономическая дифференциация внутри союза, но и феномен «беженцев» - заселение стран людьми со слабо выраженными побуждениями к труду и «выталкивание» национального населения из своих стран ${ }^{5}$.

Среди стран Восточной Европы в 1992-2013 гг. небольшое увеличение численности населения (от 0,4 до $2 \%$ ) произошло только в Польше, Чехии и Словакии.

На этом негативном фоне выгодно смотрится восточный сектор пространства бывшего СЭВ. Рост населения после 1992 г. был особенно значительным в странах Средней Азии (от $26 \%$ до $49 \%$ прироста), Монголии - на $27 \%$, и Вьетнаме - на $31 \%$, причем скорость роста их населения увеличивается во времени.

Таким образом, человеческие ресурсы азиатского сектора бывшего СЭВ укрепляются за счет высокой рождаемости,

${ }^{5}$ Этот абзац был написан задолго до референдума в Великобритании 
несмотря на эмиграцию не только русскоязычного, но и коренного их населения в Россию, а численность населения западного сектора продолжает сокращаться. Эти тенденции формируют условия для «тектонических» изменений будущей экономики на пространстве бывшего СЭВ и не могут не учитываться при создании долгосрочных стратегий поведения сибирских регионов на мировом рынке.

Если рост численности населения на пространстве СЭВ резко замедлился после 1992 г., то внешняя торговля, наоборот, после его развала начала бурно развиваться во всех без исключения странах (таблица). Если за 1970-1990 гг. суммарный экспорт этих стран вырос в 2,6 раза, то с 1990 г. по 2012 г. - в 6,1 раза 6 за счет открытия национальных экономик для мирового рынка. Рос не только импорт, но и экспорт. Суммарная экспортная квота (доля экспорта к ВВП) по всей группе стран на пространстве СЭВ без учета государств постсоветского пространства увеличилась за период с $16 \%$ до $54 \%$.

\section{Импорт и экспорт отдельных стран СЭВ} в 1970-2013 гг., млрд долл.

\begin{tabular}{|l|c|c|c|c|c|c|c|c|}
\hline \multirow{2}{*}{ Страна } & \multicolumn{2}{|c|}{1970} & \multicolumn{2}{c|}{1990} & \multicolumn{2}{c|}{2012} & \multicolumn{2}{c|}{2013} \\
\cline { 2 - 9 } & экспорт & импорт & экспорт & импорт & экспорт & импорт & экспорт & импорт \\
\hline Монголия & 0,1 & 0,3 & 0,3 & 0,8 & 2,9 & 5,4 & 3,3 & 6,0 \\
\hline Куба & 2,0 & 4,6 & 4,2 & 10,1 & 13,9 & 11,0 & 14,6 & 12,0 \\
\hline Болгария & 3,4 & 3,9 & 7,9 & 10,0 & 19,5 & 23,6 & 21,3 & 24,7 \\
\hline Румыния & 0,8 & 0,7 & 10,7 & 14,2 & 46,6 & 65,7 & 56,6 & 71,1 \\
\hline Словакия & 5,00 & 0,0 & 6,27 & 11,3 & 60,19 & 53,1 & 63,31 & 55,1 \\
\hline Вьетнам & 1,8 & 2,2 & 4,7 & 5,6 & 66,5 & 66,9 & 80,4 & 81,0 \\
\hline Венгрия & 4,8 & 6,6 & 14,5 & 12,7 & 108,6 & 96,9 & 114,9 & 102,6 \\
\hline Чехия & 10,0 & 0,0 & 21,4 & 19,8 & 132,1 & 118,3 & 132,5 & 118,6 \\
\hline Польша & 11,6 & 11,7 & 27,8 & 20,1 & 172,5 & 171,1 & 181,1 & 174,1 \\
\hline
\end{tabular}

Источник: расчеты автора по данным ООН $[6,10]$.

Но переориентация на «западный» рынок поставила ряд стран в критическую зависимость от него. Так, уровень экспортной квоты в 2013 г. в Венгрии превысил 102\%, (в 1990 г. - 16\%),

${ }^{6}$ Суммарный экспорт стран СЭВ без учета данных по СССР в 1970 г. составлял всего 34,5 млрд долл.; в 1990 г. - 91,5 млрд долл., и в 2012 г. 526 млрд долл. а это означает, что значительная часть ее импорта после увеличения добавленной стоимости возвращается на внешний рынок. Зависимость от внешнего спроса сложилась также в Монголии, Болгарии, Вьетнаме, Чехии и, особенно, в Словакии. Экспортная квота в 2013 г. в Словакии достигала 97\% (в 1990 г. - 18\%), во Вьетнаме - 92\% (26\%), в Чехии - 86\% (20\%), Монголии - 66\% (18\%), Болгарии - 61\% (в 1990 г. - 28\%).

Некоторые страны за эти годы превратились в чистых импортеров, т. е. их импорт не покрывается валютными поступлениями от экспорта. Например, устойчивое отрицательное сальдо характерно для Болгарии, Румынии, Монголии и Вьетнама. В тех странах СЭВ, в которых экспорт превышал импорт не более чем на $13 \%$, при высоком уровне экспортной квоты отмечается и значительная импортозависимость. Так, покрытие экспортом импорта превышало единицу в торговле Словакии $(1,13)$, Венгрии $(1,12)$, Чехии $(1,12)$ и Кубы $(1,26)$. В Монголии это соотношение составило 0,54 , Болгарии - 0,83, Румынии 0,71 . У Вьетнама $(0,99)$ и Польши $(1,01)$ это соотношение было близко к балансу.

Польша среди европейских стран СЭВ имеет самую низкую экспортную квоту (44\%) при самом высоком уровне экспорта, т.е. её экономика ориентирована в большей степени на производство продукции для внутреннего потребления, нежели на внешний рынок.

\section{Тенденции развития в 1970-2012 гг.: до и после роспуска СЭВ}

Возникает вопрос, какое влияние оказала интеграция в мировой рынок на экономику стран на пространстве СЭВ? Некоторое представление об этом позволяет получить анализ динамики ВВП стран-членов СЭВ и СССР за 43 года (с 1970 по 2012 гг.) (рис. 1).

На рисунке видно, что динамика ВВП Польши и Вьетнама характеризуется возрастающим трендом. Вьетнам - единственная из всех стран - демонстрирует непрерывный рост на всем 43-летнем интервале (результат эффективного управления). ВВП Польши снижался во время кризисов 1980-1982 гг. и 1989-1992 гг. Более того, ожидаемый спад, связанный с деловым циклом длительностью 9-10 лет, в ВВП Польши проявился 
в 2000 г. двухлетней стагнацией, перешедшей в последующем в ускоренный рост.

ВВП,

млн долл. США

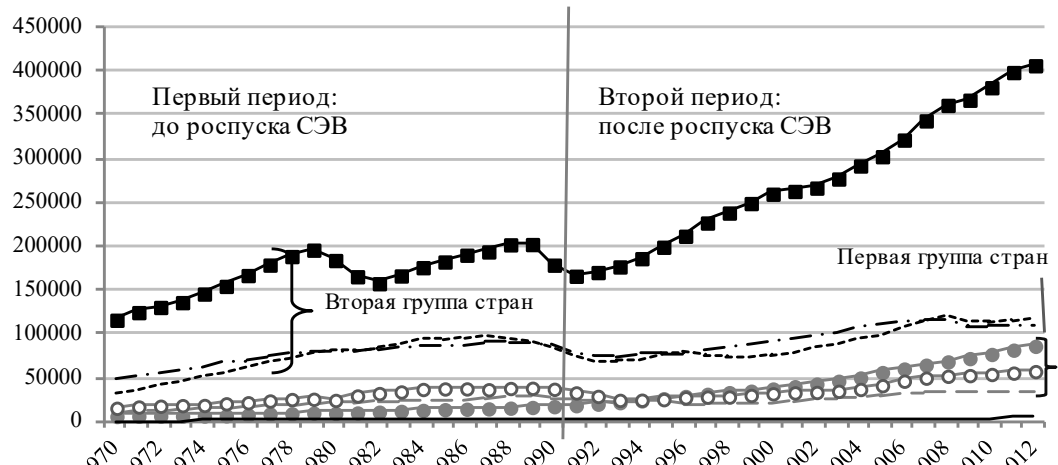

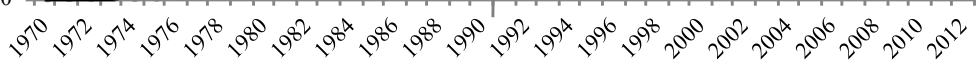

- - - - Болгария - - - - Венгрия $\longrightarrow$ Вьетнам —- Куба

$\longrightarrow$ Монголия $\longrightarrow$ Польша —-------- Румыния

Источник: расчет автора по данным ООН

Рис.1. Динамика ВВП стран на пространстве СЭВ в 1970-2012 гг., млн долл. (в ценах 2005 г.)

Соотношение объемов ВВП этих стран и СССР позволяет оценить расстановку сил на экономическом пространстве СЭВ. В 1970 г. три страны обеспечивали 85\% суммарного ВВП СЭВ: это СССР (60\%), Польша (15\%) и Чехословакия (10\%). Через 20 лет лидерство трех стран сохранилось, их суммарный вклад остался прежним, но роли изменились. Доля СССР возросла на 7\% на фоне значительного снижения вклада Польши и Чехословакии: ВВП нефтяной державы рос быстрее, нежели в Чехословакии и Польше, где рост был связан с развитием высокотехнологичных и перерабатывающих производств.

Четвертым крупным игроком была Венгрия. Ее вклад, составлявший в 1970 г. 6,4\%, в 1990 г. был ниже на 1,4\%. В целом суммарная доля всех пяти восточноевропейских стран СЭВ за 1970-1990 гг. упала с 36,6\% до 29,4\%, несмотря на незначительное усиление позиций Болгарии и Румынии. За этот период увеличились также доли Вьетнама и Монголии.
Проведенный факторный анализ позволил выявить два типа развития стран до развала СЭВ и три - после него [4, 5].

За 1970-1990 гг. из девяти стран СЭВ первый тип развития был представлен агрегирующим фактором F-1 (1990), объединившим Болгарию, Вьетнам, Кубу, Монголию, СССР и Чехословакию (рис. 2). Оценки корреляции свидетельствовали о том, что его динамика определялась, прежде всего, темпами ВВП Вьетнама, Монголии и СССР (см. рис.1, период до 1990 г.).

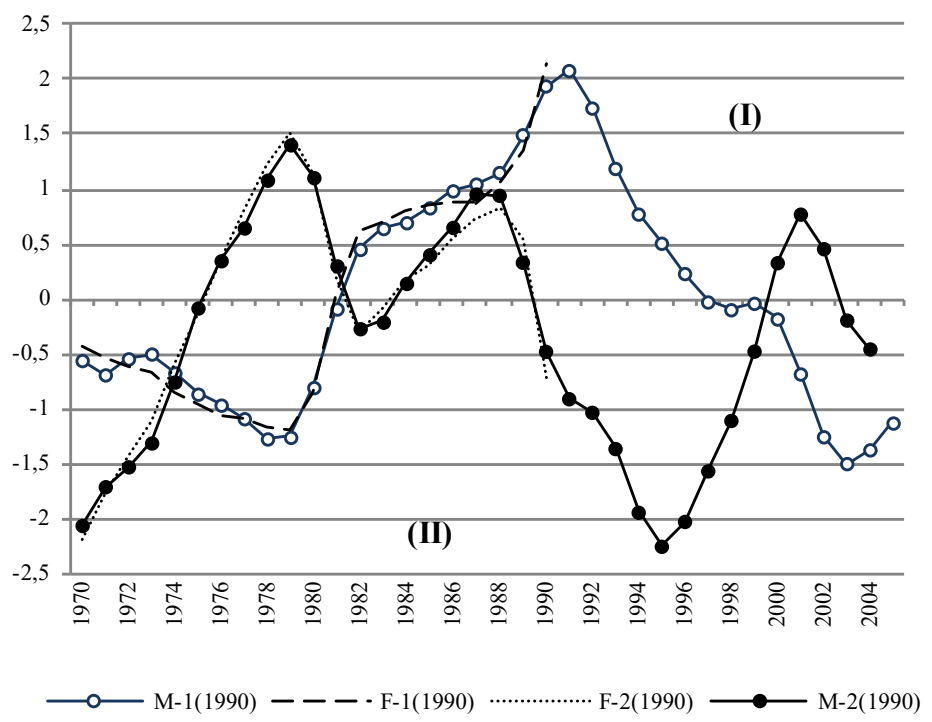

Источник рис. 2-3, 5: расчеты авторов по данным ООН в млрд долл., в ценах 2005 г. [4].

Рис. 2. Результаты факторного анализа ВВП стран СЭВ на базе 1970-1990 гг. (в ценах 2005 г.) F-1 (1990) - первый фактор; M-1 (1990) - модель первого фактора и ex-post прогноз с 1991 г. по 2003 г. F-2 (1990) - второй фактор; М-2 (1990) и еx-post прогноз с 1991 г. по 2004 г.

Во вторую группу (второй тип динамики) вошли Польша, Венгрия и Румыния, ВВП которых отображены тремя верхними графиками на рисунке 1 , а динамика агрегирующего их фактора F-2 (1990) - на рисунке 2. 
Ярко выраженные противоположные тенденции свидетельствуют о различии процессов, происходящих в экономиках двух групп стран. Смена тенденций факторов совпадает по времени и приходится на кризисные 1979 г., 1982 г. и 1988 г.7, но происходит в противоположных направлениях.

Почти зеркальное поведение обоих факторов, безусловно, было неожиданным, но еще более неожиданные результаты были получены при их моделировании, прогнозировании, из чего можно сделать нетривиальные выводы о развитии соответствующих типов стран.

Построенная с применением методов ${ }^{8}$ моделирования циклической динамики коротких временных рядов $[7,8]$ модель первого фактора, агрегирующего изменения ВВП Болгарии, Вьетнама, Кубы, Монголии, СССР и Чехословакии с высокой точностью (98\% изменений), воспроизвела его динамику на базовом периоде. При построении модели были получены статистически обоснованные оценки циклической динамики длительностью 8,4 года (деловой цикл) и 4,6 лет (либо известный цикл динамики запасов, либо влияние пятилетних планов).

Отмечая общую тенденцию роста обобщающего показателя F-1 (1990) в базовом периоде, было естественно ожидать его дальнейший рост после 1990 г. Но ex-post ${ }^{9}$ прогноз на 19912003 гг. полностью опроверг ожидания и вместо естественного на первый взгляд роста предсказал резкое замедление в 1991 г., а сразу после него длительное - до 1998 г. - падение (см. рис. 2). Методика построения любого прогноза по данным временно́го ряда базируется на памяти этого ряда. В рамках данного подхода, основанного на выявлении закономерной циклической

7Динамика факторов отражает тенденции реальныхпоказателей, взятых после стандартизации, а в прогнозном периоде смены тенденций модели ипрогноза происходят при изменении темпов роста реальныхпоказателей.

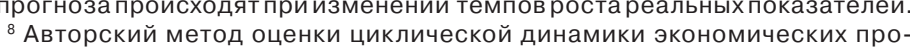
цессов был отмечен государственной премией и дипломом ГКНТ на Всесоюзном конкурсе работ по созданию методов моделирования циклического развития науки и техники (1990). В работе использована его современная модификация.

9 Ex-post - прогноз, предсказывающий прошлые (уже известные) значения исследуемых переменных на основе данных, предшествовавших последним. Предназначается для проверки точности прогнозной модели и - на этой основе - для оценки точности прогноза на будущее.

Ex-ante - прогноз на предстоящий период, разработанный на основе исследования настоящего и прошлого. характеристики процесса (если это не белый шум), полученный прогноз дает основание для гипотезы о том, что при сохранении механизмов формирования ВВП этих стран после 1990 г. следовало ожидать резкого ухудшения их развития в 1991 г. даже в случае сохранения СЭВ.

И, как вытекает из расчетов и графика ex-post прогноза, влияние механизмов, действовавших в 1970-1980-х гг., сказывалось вплоть до 1998 г. Таким образом, получается, что минимум за 20 лет, предшествующих распаду СЭВ, сформировались негативные воздействия, которые и в 1990-х. продолжали влиять на ВВП этих шести стран. Эти факторы практически на 100\% обусловили отрицательную тенденцию их развития, начиная с 1991 г. и до 1998 г.

Следовательно, экономический спад в этих странах был неминуем, и именно негативные тенденции, к которым можно отнести снижение объемов инвестиций в перерабатывающие производства, устаревание основного капитала, высокую фондоемкость и низкую фондоотдачу и др., в 1970-1990 гг. стали его определяющей причиной [8], а вовсе не распад СЭВ и СССР, как принято считать. Ликвидация СЭВ, безусловно, сказалась, но ее влияние не было определяющим в 1991-1998 гг., оно было отодвинуто во времени и, как будет ясно из дальнейшего, - со значительным лагом.

Результат был неожиданным и требовал подтверждения. Было решено воспроизвести аналогичные расчеты для реального показателя - ВВП СССР - на той же временной базе 1970 1990 гг. и сравнить прогноз с данными «условного СССР» после 1990 г., полученными суммированием ВВП стран постсоветского пространства.

И вновь, но уже на реальных данных ВВП СССР, вторично были предсказаны смена возрастающей тенденции в 1991 г. и дальнейшее падение до 1998 г. Модель, ex-post прогноз и фактические данные «условного СССР» приведены на рисунке 3. Следует отметить высокую точность модели как на имитационном (базовом) периоде, так и на прогнозном интервале вплоть до 1998 г., а также выявленные в имитационнном периоде (1970 1990 гг.) в динамике ВВП СССР усредненные по диапазону частот оценки циклической динамики длительностью 13,3 года, 8,2 и 5,8 лет. 


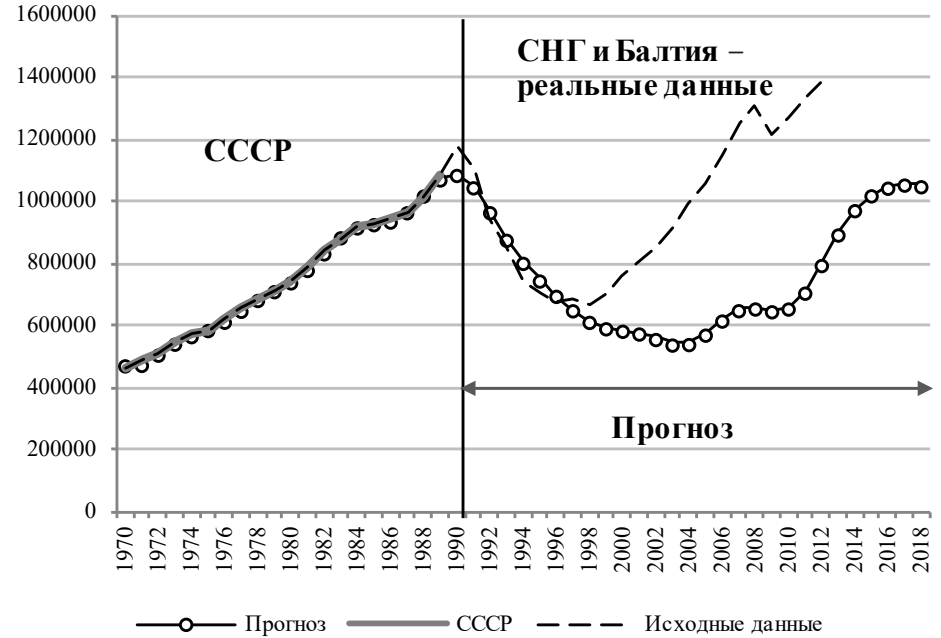

Рис.3. ВВП СССР в 1970-1990 гг.; суммарный показатель ВВП стран - бывших республик СССР («условный СССР») в 1991-2012 гг. Модель на базе 1970-1990 гг. и ex-post-прогноз на 1991-2012 гг., млрд долл.

Таким образом, расчеты модели ВВП СССР подтвердили наличие делового цикла длиной $8,2-8,4$ года, обнаруженного в динамике фактора F-1 (1990), обобщившего тенденции развития экономики шести стран СЭВ до его развала. Цикл длительностью 13,3 года ранее проявлялся в показателях развития страны как 12-летний и связан со сроками выбытия оборудования.

Не менее интересно то, что в прогнозе есть указание на будущие проблемы в экономическом развитии стран в отдаленной перспективе: 2008-2009 гг., и, следовательно, еще в 1991 г. мы могли предугадать этот экономический кризис. Более того, на рисунке 3 видно, что с 2010 г. темпы (ускорение) роста модельного и реального показателей очень близки (с небольшим превосходством темпов прогнозных значений), т. е. модель предсказала не только кризис, но и темпы выхода из него.

На рисунке также видно совпадение для отдельных лет прогнозных и фактических значений. Кроме того, предсказанное и зафиксированное в реальных данных падение совпало на интервале с 1991 г. до 1998 г. Инерционный механизм был настолько силен, что до 1998 г. развитие продолжалось по тем же законам. Итак, динамику ВВП «условного СССР» почти восемь лет определяли причины, которые возникли еще до 1990 г. и обусловили снижение ВВП новых стран на постсоветском пространстве.

Таким образом, падение экономики СССР было неизбежным. Сказывались тенденции спада, спровоцированные масштабным устареванием основных фондов (50-летний цикл Кондратьева) и оборудования (13,3-8,2-летний деловой цикл).

Если бы причинно-следственные связи, характерные для имитационного периода 1970-1980-х гг., сохранились и продолжали действовать без изменений и далее, то падение показателя должно было бы продолжаться до 2004 г., и только затем должен был начаться период роста. В реальности положительные изменения начались раньше на пять лет - в 1999 г. Здесь можно сделать предположение, что последствия развала СССР и СЭВ изза инерционности экономики начали сказываться с лагом в 7-9 лет и в целом оказали положительное влияние. Так ли это?

Рост можно было бы связать с рыночными реформами, открытостью экономик, изменением налоговых режимов и т. д. Однако это лишь часть в системе причинных факторов. Добавляются новые факторы, влияющие на развитие стран на пространстве СССР. С 1998 г. начался многолетний рост мировых цен на сырьевые товары [8], в первую очередь на нефть, что не могло не отразиться на суммарном показателе ВВП стран «условного СССР», среди которых несколько государств стали экспортерами нефти.

Моделирование мировой цены на нефть марки Brent с 1970 г. по 2012 г. позволило сделать вывод, что падение цен на нефть с 2013 г. по 2017 г. имело объективные причины, сформировавшиеся еше до 1990 г., а снижение цены по прогнозу до 2025 г. обусловлено новыми явлениями на нефтяном рынке, возникшими после 1990 г.

В динамике мировой цены на нефть зафиксирован резкий рост в 1998-2008 гг., отразившийся в ВВП стран первого типа развития. Без влияния цены на нефть после 1999 г. рост ВВП мог быть, но значительно меньше.

Что же происходило со странами второго типа развития Польшей, Румынией и Венгрией? Эти три страны еще 
во времена СЭВ выделялись на пространстве Восточной Европы высокими темпами роста. Так, в 1970 г. годовой темп роста ВВП Польши составлял 107\%, Румынии - $113 \%$, Венгрии 106\%. При этом ВВП Польши был самым высоким по объему (117,3 млрд долл.), вдвое выше, чем в Венгрии (49,2 млрд долл.), втрое - чем в Румынии (32,6 млрд долл). ВВП Польши вырос с 1970 г. почти в 3,5 раза и достиг в 2012 г. 407,6 млрд долл.

Кроме того, ВВП Польши не только не сократился после 1991 г., как в странах первой группы, но и рос более высоким темпом, чем до 1990 г., почти непрерывно до конца периода. ВВП Венгрии и Румынии в отдельные годы практически совпадали (см. рис. 1). В отличие от Польши кризисы после 1990 г. отражались для них либо более резким снижением темпов роста их ВВП, либо абсолютными падениями показателей. Несмотря на эти различия и то, что в 2009-2012 гг. в Румынии отмечалась стагнация, в Венгрии - повышенная волатильность, второй фактор объединил эти три показателя в единую группу.

На рисунке 2 на графике второго фактора F-2 (1990) после 1987 г. начинается период негативного развития, который по полученному прогнозу (модель М-2 (1990)) для этой тройки стран должен был продолжаться вплоть до 1995 г., что не подтвердилось в реальности: результаты прогноза не совпадали с динамикой развития этих стран, как для первой группы.

В действительности с 1992 г. ВВП Венгрии медленно возрастал, в Румынии после глубокого спада 1988-1991 гг. был рост до 1996 г., в Польше после спада 1989-1991 гг. начался интенсивный рост до конца периода. По прогнозу рост должен был начинаться только в 1996 г. (см. рис. 2).

Так или иначе сравнение прогноза с реальной динамикой ВВП на 1990-2012 гг. позволяет высказать гипотезу, что на экономике Польши, Румынии и Венгрии выход из СЭВ сказался положительно и практически сразу.

\section{Экономическое пространство СЭВ после появления 16 новых стран ${ }^{10}$}

Страны постсоветского пространства, представленные единым субъектом, за последующие после развала СЭВ и СССР

\footnotetext{
${ }^{10}$ С учетом Чехии и Словакии.
}

20 лет значительно потеснили своих бывших соучастников по интеграции. В структуре ВВП доля постсоветского пространства, объединенного в показатель «условный СССР», выросла с 1991 г. по 2012 г. на 7,75\% и приблизилась к 75\% суммарного ВВП стран бывшего СЭВ. Увеличилась и доля Вьетнама на $0,9 \%$, притом, что все остальные страны-участницы снизили свои доли в диапазоне от 2,5\% до 0,4\%. ВВП стран Восточной Европы в сумме опустился до 21,4\% относительно 1991 г., что означало снижение на 7,2\%, а относительно 1970 г. - на 15,2\%.

Однако важно отметить, что темпы роста экономик стран бывшего СССР далеко не так оптимистичны.

Экономика на втором этапе росла самым быстрым темпом во Вьетнаме $(11,7$ раза) и в Монголии $(7,3$ раза), т. е. в странах, у которых стартовые позиции 1991 г. были самыми низкими. Результаты Кубы, Польши и Румынии были значительно скромнее. Они увеличили свои ВВП за два последних десятилетия примерно в 3,5 раза, Болгария - в 3,2 раза. При этом суммарный ВВП на постсоветском пространстве, доля которого увеличилась на $7,75 \%$, вырос всего в 2,9 раза, опередив по темпам только Венгрию (2,2 раза). Таким образом, проявляются скрытые тектонические сдвиги в тенденциях развития на пространстве СЭВ, которые неминуемо приведут к кардинальным изменениям.

Одновременно меняется расстановка сил между странами бывшего СССР. Сопоставление страновой структуры ВВП на постсоветском пространстве в 1991 г. и 2012 г. показывает, как разворачивается вектор экономического развития на восток и с какой скоростью.

Накануне распада СССР по объемам ВВП лидировали Россия (ее доля от суммарного ВВП составляла 72\%), Украина $(11,7 \%)$ и Казахстан $(4,3 \%)$, замыкали список Таджикистан и Кыргызстан. В 1991 г. всего 2,1\% приходились на ВВП Литвы и $2 \%$ - на ВВП Беларуси, вклад каждой из остальных республик не превышал $1,4 \%$.

В 2012 г. свои доли в суммарном ВВП на постсоветском пространстве увеличили Беларусь (рост на 1,3\%), Казахстан - на $2 \%$, Азербайджан - на 0,77\%, Туркменистан и Узбекистан - по 0,9\%. Увеличили, хотя и ненамного, свой вклад Эстония - на $0,3 \%$, Армения и Литва (на $0,1 \%$ каждая).

Вес этих стран рос на фоне падения доли остальных. Самое большое снижение (притом, что эти страны сохранили свои места 
и в рейтинге 2012 г. по объемам ВВП) отмечалось у Украины на $4,8 \%$ и России - на $0,9 \%$. Грузия и Молдавия потеряли по $0,3 \%$ каждая, Латвия $-0,2 \%$.

Если до развала СССР его развитие определяла экономика России, то после распада Союза новые страны развиваются не только под ее влиянием, но и под воздействием общих закономерностей, как внутренних, так и внешних. Об этом свидетельствует почти полное совпадение на всем периоде 1991-2012 гг. изменений динамики ВВП РФ и суммарного ВВП остальных республик, отнесенных к их уровням 1990 г. (избавившись от масштабов показателей, мы получили возможность сравнить их динамику) (рис. 4). Это позволило оценить глубину падения в середине 1990-х гг. и увидеть то, что в 2005 г. и 2008 г. ВВП стран находился на уровне 1990 г.

$$
\%
$$

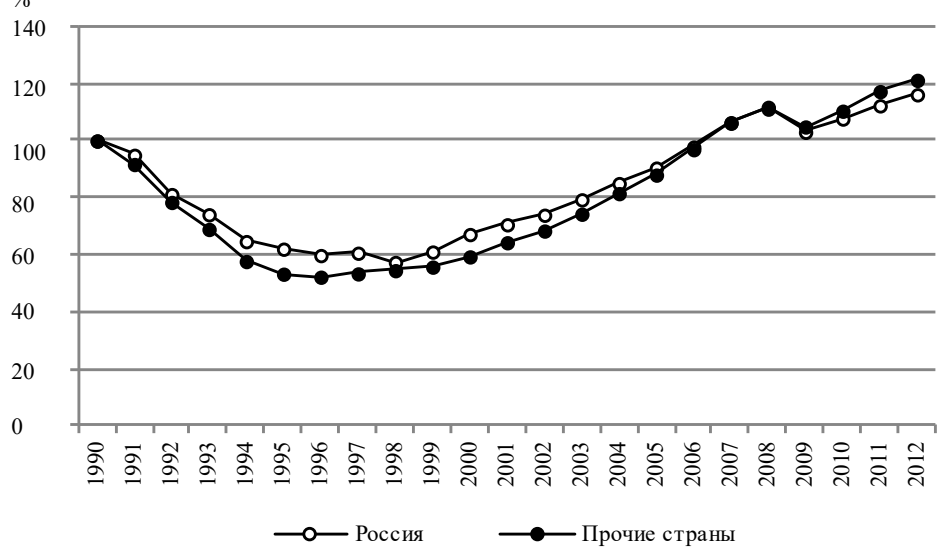

Рис.4. ВВП России и остальных стран постсоветского пространства в 1990-2012 гг., \% к 1990 г.

Принципиальное различие тенденции наблюдалось только однажды - в 1998 г., когда темп ВВП России упал, а у объединенной группы стран продолжился рост. Следует отметить и то, что после 2009 г. превышение темпа роста России, наблюдавшееся в 1990-2008 гг., сменилось устойчивым отставанием от динамики суммарного показателя: Россия после 2009 г. начала отставать в своем развитии в сравнении со странами остальной территории СССР.

\section{Результаты факторного анализа ВВП 24 стран (1991-2012 гг.) на пространстве СЭВ: модели и прогнозы}

На втором этапе исследований были получены три фактора и соответствующее распределение стран по трем группам, или типам развития. Первый фактор F-1 (2012) объединил 10 стран первого типа: Узбекистан, Туркменистан, Монголию, Вьетнам, Польшу, Азербайджан, Беларусь, Словакию, Кубу и Казахстан. Сюда вошли энергообеспеченные республики Средней Азии, Азербайджан, Казахстан, а также страны с более высоким темпом роста экономик.

Второй фактор F-2 (2012) объединил все три страны Балтии, а также Болгарию, Армению, Венгрию, Румынию и Чехию. Для второго типа стран, в отличие от первой группы, был характерен не рост с 2007 г., а длительный спад вплоть до 2012 г. (рис. 5). Первые две группы стран объединили и бывшие республики СССР, и страны-члены СЭВ.

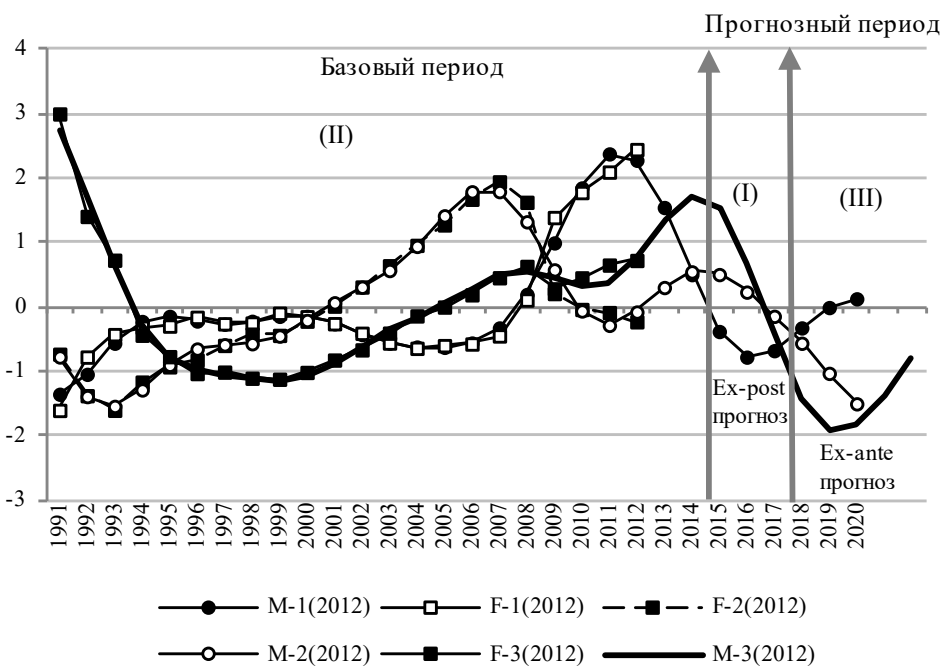

Рис. 5. Факторы, модели и прогнозы ВВП бывших стран СЭВ на 2012-2020 гг.

По сравнению с результатами факторизации пространства первого периода наблюдались следующие изменения. Так, Польша 
перешла в первую группу, а Венгрия и Румыния, которые в 1970 1990 гг. были с ней в одной группе, остались во второй. В разные группы вошли Словакия (1-й фактор) и Чехия (2-й фактор).

Модель M-1 (2012), построенная для фактора F-1 (2012), несмотря на увеличение ВВП с 2007 г. по 2012 г., меняет темп роста в 2011 г. и далее предсказывает спад до 2016 г. (что означает снижение либо темпа роста, либо абсолютных значений реальных показателей). В динамике этого фактора (напомним, что он объединил страны с высоким темпом развития, в том числе Польшу, Казахстан и Беларусь) обнаружены закономерности, соответствующие деловому циклу с периодом 8-12 лет (средний срок службы оборудования) и периодом шесть лет - «солнечному» циклу. При этом первым по значимости в формировании дисперсии был 12-летний цикл.

Тенденции развития первой и второй групп стран носят противоположный характер: на время спада первого фактора приходится рост второго, и наоборот.

Максимальное за весь период значение второго фактора было достигнуто в 2007 г., когда страны первой группы только подошли к фазе подъема. Напомним, что во вторую группу объединены государства с более низкими темпами развития, в том числе страны Балтии, Болгария и Румыния. В 2007 г. в динамике ВВП этих стран начинается длительное падение до 2012 г., и естественным кажется дальнейшее снижение показателя. Однако модель М-2 (2012) показала рост их экономик с 2011 г. по 2014 г., стагнацию в 2015 г. и лишь затем - резкое обрушение, предсказав для второго типа стран продолжение негативной тенденции развития с 2015 г. вплоть до 2021 г.

Обнаруженные среднесрочные циклы с периодами 9,4 и 13 лет - более длительными, чем в странах первой группы, могут быть обусловлены более продолжительным сроком службы оборудования, что характерно и для стран постсоветского пространства. «Солнечный» шестилетний цикл также был обнаружен, и его оценки практически совпали.

Неожиданно третий фактор F-3 (2012) объединил в один тип развития шесть стран, приведенных в порядке снижения корреляции ВВП страны с этим фактором: Украину (коэффициент корреляции 0,955), Молдавию, Грузию, Таджикистан, Кыргызстан и Россию, т. е. только страны постсоветского пространства.
Это страны с высокой политической активностью и локальными военными действиями на их территориях.

Из динамики их фактора F-3 (2012) (рис.5) следует, что все эти страны были более остальных подвержены отрицательному влиянию развала СССР: в их экономиках негативное развитие началось с 1991 г. и продолжалось до 1999 г. Дальнейший рост оказался незначительным, был прерван годовым спадом в 2008 г. и продолжался с замедлением до 2012 г. Кроме того, за весь период агрегированный показатель так и не достиг уровня 1991 г. В структуре показателя выявлены циклы: деловой - 8,2-12,3 лет и солнечный - 6,2 года, что лучше, чем во второй группе, и почти совпадает с оценками первой группы стран.

Медленное, но длительное повышение уровня третьего фактора после 1999 г. давало основание надеяться на дальнейший рост, и в отличие от прогнозов двух первых факторов, эти ожидания были оправданны. Модель М-3 (2012) предсказала рост фактора с 2011 г., но только по 2013 г. В 2014 г. началось снижение, а с 2015 г. по прогнозу эту группу стран ждет длительный спад, который прекратится лишь в 2019 г. (напомним, что память модели не включала события 2013-2015 гг., а реальность 2014-2016 гг. подтверждает полученный прогноз).

Опыт членства в СЭВ до и после его закрытия позволил получить ряд неожиданных и интересных результатов.

Первое. Активная внешнеэкономическая позиция Польши в торговле со странами СЭВ и одновременно с Западной Европой обеспечивала ей значительные преимущества в экономическом развитии. Более тесная интеграция, активная инвестиционная политика, особенно по привлечению иностранного капитала, вступление в ЕС впоследствии способствовали высоким темпам роста вплоть до 2012 г.

Агрегированная динамика ВВП Польши и стран, входивших в первую группу, полностью противоположна показателям третьей группы стран, куда входит СССР, а затем Россия.

Второе. Совет экономической взаимопомощи не реализовал свои возможности и не достиг поставленных целей. За 20-летний период его существования проявились негативные 
закономерности, которые влияли вплоть до 1998 г. Именно они стали определяющей причиной экономического спада в странах в первой половине 1990-х годов, а не распад СЭВ и СССР, как это предполагалось.

Таким образом, и развал СССР, который, кстати, был осуществлен с нарушением всех норм международного права, также лишь усугубил экономическую ситуацию в первом десятилетии рыночных отношений, а длительный экономический спад в 1990-х был определен ходом экономического развития в предшествующей истории.

Третье. Факторный анализ ВВП 24 современных стран на пространстве бывшего СЭВ позволил разделить их на три группы по сходству их развития (в скобках указано членство в EC).

Первую группу составили Вьетнам, Монголия, Польша (ЕС), Куба, Азербайджан, Беларусь, Казахстан, Туркменистан, Узбекистан и Словакия (ЕС). По прогнозу, выход из кризиса приходится на 2016 г. Их доля в торговле Сибирского федерального округа в 2014 г. (без учета Казахстана и Беларуси) составляла $6,7 \%$ в экспорте и $3,6 \%$ - в импорте [9].

Вторая группа объединяет Венгрию (ЕС), Эстонию (ЕC), Латвию (ЕС), Литву (EC), Чехию (EC), Армению, Румынию (EC), Болгарию (EC). По прогнозу, кризис для этой группы будет продолжаться до 2021 г. (возможно, и далее). Их доля в торговле с СФО в 2014 г. составляла 2,7\% в экспорте и 1,73\% - в импорте [9].

В третью группу вошли Россия и страны постсоветского пространства с высокой политической активностью и локальными военными действиями на их территориях: Украина, Молдавия, Грузия, Таджикистан, Кыргызстан. По прогнозу перелом в экономике для этой группы стран должен наступить в 2019 г. Их доля в торговле с СФО в 2014 г. (без учета Казахстана и Беларуси) составляла 6,3\% в экспорте и 11\% - в импорте [9].

Bсе три группы стран переживают проблемы в экономике, но их развитие происходит с различной динамикой и имеет различные перспективы. Уже сейчас можно считать приоритетным расширение контактов России и СФО со странами первой группы, куда входят Вьетнам, Монголия, Куба, Азербайджан, Беларусь, Казахстан, Туркменистан, Узбекистан, Польша и Словакия. Окончательные выводы требуют более скрупулезного изучения современных интеграционных институтов и перспектив торгового сотрудничества с каждой страной отдельно с учетом их ориентации.

\section{Литература}

1. Комментарий к Договору о Евразийском экономическом союзе [Эл. ресурс]. URL: http://www.brokert.ru/material/dogovor-ecraziyskiyekonomicheskiy-soyuz (дата обращения: 15.11.2015).

2. Ковалёва Г. Д., Коклягин Е. Г. Экспорт и импорт Сибири в зеркале таможенной статистики // ЭКО. - 1994. - № 2. - С. 3-24.

3. База статистических данных UNdata [Эл. ресурс]. URL: http://data. un.org/ (дата обращения: 15.11.2015).

4. Ковалёва Г.Д. Концептуальные основы исследования экономической безопасности региона в области ВЭД // Экономическая безопасность России: проблемы и перспективы: материалы 2-й Междунар. науч.-практ. конф. ученых, специалистов, преподавателей вузов, аспирантов, студентов / [ред. кол.: С. М. Дмитриев и др.] Нижегородский гос. тех. ун-т им. Р. Е. Алексеева. - Нижний Новгород, 2014. - С. 169-174

5. Шевелев А. А. Экономическое развитие Польши в статистическом сопоставлении со странами - участниками бывшего СЭВ (сегодня и в ретроспективе) // Экономическое развитие России: региональный и отраслевой аспекты: сб. науч. тр. Вып. 13 / Под ред. Е.А. Коломак, Л В Машкиной; ИЭОПП СО РАН - Новосибирск, 2014 - С. 149-165. 6. Shevelyev A. Historical aspects and the place of Poland's foreign trade in the countries - former members of the Comecon // Local production systems: analysis and forecasting of regional economic development: [collection of papers] / ed. by A.S. Novoselov, V. E. Seliverstov; Institute of Economics and Industrial Engineering, University of national and world economy, MatejBel university BanskaBystrica, Ternopil national economic university, University of Lodz. - Novosibirsk-Sofia-Lodz-BanskaBystricaTernopil: IEIE SB RAS, 2015. - P. 303-308. URL: http://lib.ieie.nsc.ru/ docs/2015/LocalProdSyst2015/303-308Shevelev.pdf

7. Ковалёва Г.Д. Применение теории временных рядов в экономических исследованиях: курс лекций / [Отв. ред. Г. М. Мкртчян]; Новосиб. гос. ун-т. - Новосибирск, 2008. - 53 с.

8. Ковалёва Г.Д. Циклическая динамика экономических процессов Измерение и моделирование / отв. ред. Б. Б. Розин; ИЭОПП СО РАН. Новосибирск: Наука. Сиб. отд-е, 1992. - 156 с.

9. ФСГС. URL: http://stu.customs.ru/index.php?option=com_content\&vi ew $=$ category \&id $=180: 2012-12-27-01-28-54 \&$ ltemid=255\&layout=default (дата обращения: 25.03.2016). 